\title{
Changing Market Scenario for Indian Tea
}

\author{
Kakali Hazarika
}

\begin{abstract}
Tea has occupied an important place in India's economy for the last several decades. The market for Indian tea is changing day by day. In global scenario, Indian tea is losing its position due to high price and poor quality. And in domestic market also tea is facing tough competition from soft drinks and other beverages like horlicks, bournvita etc. The traditional tea industry was production oriented. But now to meet the competition, a new market orientation is emerging. The market production linkage can be strengthened by either Market creation or Market matching. Market creation means attempt to create new markets. It represents an active approach to linking production to markets. In market matching there is very little effort to influence the market. Here a product is sold to match the market demand. Few years back tea industry has the market matching approach. But now both market creation and market matching are needed to face the demand of the market.
\end{abstract}

Index Terms-About four key words or phrases in alphabetical order, separated by commas.

\section{INTRODUCTION}

Ever since tea was accidentally discovered by Emperor Shen Nong in China in 2737 B.C., it has become one of the cheapest and most widely consumed beverages. The tea industry in India was created to satisfy England's desire for higher quality black tea and hence the East India Company brought tea to India from China. Since then tea industry became one of the major driving forces of Indian economy. Indian tea industry is well established in the global market, in terms of production, consumption and export. Country produced 966 million $\mathrm{kg}$ of tea in 2010, of which 76 percent is produced in the North-Eastern states. Being the largest consumer of tea, it consumes 837 million $\mathrm{kg}$ in 2010. About 203.86 million $\mathrm{kg}$ tea is exported from India which brings about US \$ 413 million as foreign exchange for the country per annum. Tea industry is a crucial source of revenue for the country. Being a labour intensive industry, it plays a vital role in employment generation. A sizeable amount of staff and labour are directly engaged in tea industry (Baruah 2008).

\section{PROBlems FACED BY THE INDUSTRY}

Indian tea industry has a 170 year old history and since then it is contributing to the country's national income. But, since late 1990s this industry is passing through a crisis stage (Asopa 2007). The causes of this crisis are:

Manuscript received April 20, 2011; revised July 30, 2011

Kakali Hazarika (Research scholar), Department of Humanities and Social Sciences, National Institute of Technology; Silchar-788010, Assam. Email :ziasarmah@gmail.com; Contact no. 9854835154
- Emergence of new growers (like Vietnam, Indonesia and Kenya) in international market results oversupply of tea. So Indian tea is facing tough competition.

- Indian tea is losing its position in the export market on account of higher production cost and poor quality.

- Tea is mostly sold through auction. But this is one sided operation which is manly controlled by brokers. Proper price realization is doubtful in this system because it is said that brokers have a good cooperation with big buyers in auction to keep the price low (Das 2008).

- Existence of higher percentage of ageing bushes is a major problem faced by the industry. It leads to low rate of production and degradation in quality.

- Higher production cost is another problem faced by the industry. Around 80 percent of the cost of production goes towards fixed expenses like fuel, power and labour (Baruah 2008).

- Lack of sufficient and up-to-date statistics regarding tea sector. Proper planning and fund utilization is not possible without this.

- Ignorance of consumers about the market structure also creates problems for the industry.

Although there are lots of problems faced by the tea industry, this paper will highlight only on the problems related to marketing of tea.

\section{The MARKeting Problems}

Among the various modes of disposal auction is most preferred mode for tea. In India, out of $800 \mathrm{mkg}$ bulk packaged tea, $500 \mathrm{mkg}(62.5 \%)$ is sold through public auction annually (Das 2009). The participants of auction system are auction organizers, seller or producers, brokers, buyers and warehouse keepers. Here producers send tea for auction. On arrival of this tea, it is stored at registered warehouses which in turn forward "arrival and weighment report" to the brokers concerned. This report contains details of the date of arrival, grade of tea and actual weights received by the warehouse. Once the tea has been catalogued, the brokers collect samples from each lot for distribution to the buyers. Brokers also draw samples for their own tasting and valuation of tea. These valuations are distributed among buyers and form a guide line for price levels at which the tea is expected to sell.

On the given date of auction, usually early in the morning auction commences. Each broker sells by rotation. Bidding starts once the auctioneer announces the lot number to be sold. Each lot is sold or "knocked down" to the highest bidder. After sale, brokers issue "Delivery order" of tea purchased by the buyer. On presentation of these documents, buyers are able to take delivery of tea from warehouse. In order to place all the teas of various qualities on a single forum and yet 
retain the capacity to sell large quantities at the right prices, the auction system has been found to be the most useful method. In its 174th year (since the first auction sale in 1837 at London) the auction system has clearly withstood the passage of time. But it is seen that here brokers are given all the power from tasting to delivering. The whole system is operated by limited number of brokers. Producers which are the caretaker of tea do not have any active role in auction system. The auction buyers are mostly big tea companies having their own network of blending, packaging and marketing. Many industry insiders believe that the large buyers have co- operated with the brokers on the auction floor to keep tea price low (Choudhury 2006). Hence actual growers can do nothing regarding the price of their tea. They cannot hold on to their stocks for a long time and so have to be satisfied with the price fixed by the big buyers. Thus producers are selling their tea to the buyers.

Many people think that selling and marketing are same. But it is not true. Selling is one activity of marketing process. Here customers are influenced to buy a product. But marketing involves a longer process of building a brand and pursuing the customer to buy it even if they do not need it. In tea industry, marketing part is done by the auction buyers i.e. big tea companies like Hindustan Lever Ltd, Tata tea, Brook bond etc. These big companies have very few gardens of their own or most of them have not. Even they are market leaders of tea. Actual marketing of tea starts after auction. This process involves blending, packaging, advertising, wholesaling and retailing of tea.

TABLE 1: TOP BUyERS OF GUWAHATI TEA AUCTION CENTRE AND THEIR SALE VOLUME

\begin{tabular}{|c|c|c|c|}
\hline \multirow{2}{*}{$\begin{array}{l}\text { S. } \\
\text { no. }\end{array}$} & Names & 1994-1995 & $2000-2001$ \\
\hline & & $\%$ to total sale & $\%$ to total sale \\
\hline 1 & Brook bond India Pvt Ltd & 30.71 & \\
\hline 2 & Lipton India Pvt Ltd & 19.04 & \\
\hline 3 & Tata Tea Ltd & 5.03 & 5.51 \\
\hline 4 & Lipton India Export Ltd & 4.64 & \\
\hline 5 & Bond Ltd & 1.83 & \\
\hline 6 & D. Dayalbhai \& Co. & 1.38 & 1.16 \\
\hline 7 & J. V. Goyal \& Co. & 1.15 & 2.01 \\
\hline 8 & Kesaria \& Co. & 0.93 & 1.76 \\
\hline 9 & Duncan Tea Co. & 0.82 & 1.09 \\
\hline 10 & Harry \& Co. & 0.76 & \\
\hline 11 & Hindustan Lever Ltd & & 21.49 \\
\hline 12 & Purbanchal Entp & & 2.55 \\
\hline 13 & Estern Entp & & 1.78 \\
\hline 14 & Eastern Agency & & 0.98 \\
\hline 15 & Kesaria Export & & 1.16 \\
\hline
\end{tabular}

In most of the agricultural produces, value addition is done at the downstream; in the higher processing and retailing stages of supply chain (Das 2009). This is also true with tea. Value is added to tea leaves at each stages of processing. As tea is ready to drink item, the downstream stages such as blending, packaging and ultimate marketing are the most profitable one. And here all the profit margins are collected by the big companies (Baruah 2008). Around 85 pc of world tea production is sold by a few Multi National Companies (MNCs) with their enormous marketing skill.

List 1: MNCs dominating the Global tea trade

- Unilever (Brook Bond, Lipton/ Unilever Trading Company UTC, UK- The Netherlands)
- Van Rees (Trader/ Blender, supplying many packers, part of Deli Universal Corporation, Netherlands)

- James Finlay (Trader, Producer, Packer, UK)

- Tata Tetley/ Stansand (Producer, Trader, Packer, UK)

- List 2: Important Tea Packer in the world

- Unilever (Lipton is a very strong brand with a world market share of $10 \%$ )

- Tetley

- R. Twining (Associated British Foods)

- Ajeepay Group (Typhoo tea)

- Ostfriesche Tee Gesellschaft- OTG: (Major German company which also has activities outside Germany)

\section{FINDINGS OF PRODUCTION SURVEY}

In tea industry producers are not actual marketers and they do not want to be. A survey conducted on tea production in Jorhat district of Assam shows:

- Almost 90 pc of the gardens are more than 80 year old and they are belonging to the same owner since establishment. So the owner has great influence on the decisions of production or sale.

- Among the observed gardens more than 80 pc are satisfied with public auction system. Here they have less effort to sell their tea. Even they are satisfied with all the activities done by brokers.

- The production cost of per $\mathrm{kg}$ made tea is approximately between Rs 55 to Rs 90, which is sold more than Rs 100 per $\mathrm{kg}$ in auction. So producers have a profit margin on their tea.

- Mostly the minimum price of the tea for auction is decided by the higher authority. Garden management only follows their direction in tea disposal.

- More than $80 \mathrm{pc}$ gardens are satisfied with the price of tea in auction and hence they do not think about branding.

- Majority of the observed gardens said that branding, packaging etc are not their task. Actually they do not want to waste time, energy and money on it. Some of them said it means relating himself with lots of new marketing problems.

- $30 \mathrm{pc}$ gardens are thinking about marketing of tea. But they do not have enough funds for it. If Tea Board will give them financial assistance they can go for it.

From the above observations it is clear that producers are satisfied with auction system regarding it as an effortless smooth process of tea disposal. So they do not want to think beyond it. It is seen that the garden management comprises of some employees only. They are paid for their duties. Hence they are not bound to think about better quality, new technology, market price etc. of tea as these are not included in duties. On the other hand it is observed that $80 \mathrm{pc}$ of the gardens are in same condition since last 10 years in case of production, infrastructure, labour problems etc, in most of them production is decreasing due to less attention by the management. Rate of replantation is also very low. The profit margin in production is very negligible; so developments of the garden are lagging behind. 


\section{RECOMMENDATIONS}

As an impact of globalization, competition is increasing in every field. So tea producers must think beyond auction. Till 2001 , it was mandatory for the producers to sell 75 pc of their tea through auction, following the Tea (Marketing) Control Order 1984. After the abolition of this order in 2001, producers were given freedom to sell their tea through the channel they prefer. So now they can go for direct sale.

Tea is enjoyed by every class of society irrespective of status and age. India as well as Assam has an international identity more than 160 years back for its tea industry. This identity was established by British and till now we are enjoying its pride. On the basis of the special characteristics of Darjeeling tea, Assam tea and Nilgiri tea India can achieve a stable position in tea market.

In the year 2007 The Union Government has launched a 'Special Purpose Tea Fund' towards accelerating the replantation and rejuvenation activity on tea gardens. Here center will pay a subsidy of $25 \mathrm{pc}$. The beneficiary gardens will have to contribute $25 \mathrm{pc}$ and $50 \mathrm{pc}$ will be given as soft loans by financial institutions. Producers can take benefits of this scheme and this will help them in quality improvement of the garden. (www.thehindubusinessline.com/2007/08/31/ stories)

India has a vast domestic market from the vary inception of this industry. Almost $80 \mathrm{pc}$ of India's annual the production is consumed by its population. In the year 2010, India's domestic consumption was $837 \mathrm{mkg}$. Maharashtra consumes highest amount of India's total tea consumption which is 87 mkg.(Wal 2008)

India tea grower can promote brands like 'Indian tea', 'Assam tea', 'Darjeeling tea' etc to sell in domestic market. So that Indian consumers can enjoy the goodness of native tea.

A marketing department is very much essential for tea producers. To survive in the long run, producers must follow product development and marketing. Today, Indian tea producers are satisfied with auction prices. But with the increasing competition, near future only best quality tea will be accepted for auction also. So investment on market creation is becoming essential for them (Das 2009).

Government of India with the collaboration of Tea Board can promote private sale of tea in some selected cities. The intension should be to create a direct contact between producers and buyers (Baruah 2008). In order to accelerate the market of tea, incentives should make to include tea in Trade fairs, Expos etc. where people will have all the varieties of tea in same place.

\section{CONCLUSION}

Ever since the commercial production of tea had started in India, tea growers did not give much attention on the marketing aspect as they always enjoys a ready made market for their product. But in the recent past due to over supply of tea against demand, the market strategy has shifted from the seller market to the buyer market. Though export market of Indian tea is losing its position, the next alternative will be domestic market, which has a trend in increase in demand. The tea producers should try to understand market demand which is very important for long term sustainability of the industry. If they take proper initiative in the marketing field, they can achieve higher margin of profit. Also it will establish Indian tea in its own brand name. Government of India and Tea Board must give them helping hand. The auction price of tea came down from Rs 76 per $\mathrm{kg}$ in 1998 to about Rs 56 per kg in 2003. As a result about 54 gardens were closed during this period, out of which 20 are in West Bengal, 17 in Kerala, 11 in Assam and 6 in Tripura and about 28000 workers were affected due to closure (Business line, 22nd July 2004). Repetition of this type of situation can destroy the Indian tea industry from the global tea map.

\section{REFERENCES}

[1] Antrobus H.A. (1957) A History of the Assam Company: 1839-1953; $\mathrm{T} \&$ A Constable Ltd; London.

[2] Asopa, V. N. (2007) Tea Industry of India: The Cup that Cheers has Tears; Indian Institute of Management, Ahmedabad; India.

[3] Awasthi R.C. (1974) Economics of Tea Industry in India; United Publishers; Panbazar; Guwahati; India.

[4] Baruah Dr. Prodip (2008) The Tea Industry of Assam, Origin and Development; EBH Publisher Guwahat; India.

[5] Banerjee Srijeet \& Banerjee G D (2008) 'Global Tea Trade: Dimension and Dynamics'; Abhijeet Publication; New Delhi; India.

[6] Bezbarua H.P.(1999) Origin \& History of Development of Tea; Global advance in tea science; A journal by Aravali Books International pvt Ltd; New Delhi; India.

[7] Choudhury, Dr Rabindra Kumar (2006) Indian Tea Industry and Assam. http://www.nenanews.com

[8] Das Ashim $\mathrm{Kr}$ (2009) Sustainability in tea industry: An Indian perspective; The Social Scanner; Akansha Publishing House; New Delhi.

[9] Das H. N. (2008) Assam Tea: Problems and Prospects; in Origin and Development of tea; EBH Publisher; Guwahati.

[10] Goddard, Samanth (2005) Tea Break: A crisis brewing in India. Action Aid, UK.

[11] Gupta Rahul (2007) 'World Agricultural Trade: WTO Perspective'; The ICFAI University Press; Kolkotta; India.

[12] Sarkar J. K. (1972) 'The Supply and Demand function of tea' in World Tea Economy; Oxford University Press; Calcutta; India.

[13] Taknet D K (2002) 'THE Heritage of Indian Tea: The Past, The Present and the Road Ahead'; Vedams e Books (P) Ltd; New Delhi; India

[14] Wal Sanne Van Der (2008) Sustainability Issues in the Tea Secto- A Comparative analysis of six leading producing countries; SOMO Publication; Amsterdam; The Nether land.

[15] www.thehindubusinessline.com/2007/08/31/stories

[16] www.thehindubusinessline.com/2004/07/22/

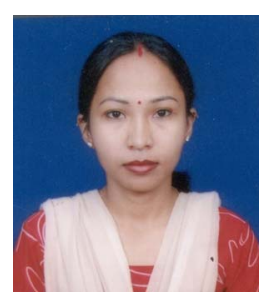

Kakali Hazarika has joined as a research scholar in the department of Humanities and Social Sciences, National Institute of Technology, Silchar in 2008. She has completed her bachelors' degree from Dibrugarh University in the year 2004 and masters from the same university in 2006 in Economics. Presently she is working on Tea Marketing Problems of Assam.

She has her credit over three research papers and articles in referred journals of national repute. Besides she has presented papers and participated in over two national seminars.

Ms Hazarika is receiving the doctoral fellowship given by ICSSR, New Delhi for her further research. 